\title{
Facing Industrial Era 4.0 Through Officers' Professionalism Improvement: Analysis of Indonesian Navy Material Worthiness Service Department.
}

\author{
Mulyadi, R.Madhakomala, Kazan Gunawan
}

\begin{abstract}
Professionalism indicates people attitude on their mastery of science. It is shown through the product of creativity and innovation they struggle with among their work circumstances. The officer of Navy Material Worthiness Service Department (DISLAIKMATAL) has an essential chore, especially on the Worthiness of all materials in Indonesian Naval Department. One hundred and twenty four officers have been investigated as the sample of research. The study found that work commitment has a dominant role to improve an officer professionalism. It seems to be a concern of the leader. In addition, both factors: transformational leadership and officer competency come as components in building the professionalism. This study applied a quantitative approach through Path analysis. The direct effect of transformational leadership (X1) on professionalism $(Y)$ is 0.2281 . The direct effect of competence (X3) on professionalism $(Y)$ is 0.270 . The direct effect of work commitment $(X 4)$ on professionalism $(Y)$ is 0.371 . The data shown that the officers professionalism will increase if they have work commitments. It is strengthened by officers" self-confidence at work. This finding deserves to be follow-up. As wish as it can improve the professionalism of Navy Material Worthiness Service Officers.
\end{abstract}

Index Terms: Transformational Leadership, Trust, Organizational Citizenship Behavior.

\section{INTRODUCTION}

Officers are an important and valuable assets for an organization. The importance of officers expressed in research on the perspective of Indonesian officers states that officers are a source of sustainable competitive advantage for an organization (Wirawan, 2015). Employee professionalism is a fundamental requirement at this time (Dilday, Miller, Schmitt, Davis, \& Davis, 2018). This is what encourages the researchers to be interested in examining the professionalism of DISLAIKMATAL officers, the role of Dislaikmatal is very complex and strategic in the in the continuation of the Navy's organization. Professional officers are a basic need (Stone-Johnson, 2017) for Dislaikmatal in carrying out its functions.

As the National Executing Agency (Balakpus) of the

Revised Manuscript Received on October 15, 2019

Mulyadi, Human Resources Management, Universitas Negeri Jakarta, Jakarta Timur, 13220, Indonesia., mulyadi.unj30@gmail.com

R.Madhakomala, Faculty of Education, Universitas Negeri Jakarta, Jakarta Timur, 13220, Indonesia.

Kazan Gunawan, Human Resources Management, Universitas Negeri Jakarta, Jakarta Timur, 13220, Indonesia.
Indonesian Navy, Dislaikmatal acts as an organization responsible for organizing the material Worthiness of development in the Indonesian Navy. Worthiness development is carried out in order to guarantee that each Weapon System Primary Equipment (Alutsista) of the Indonesian Navy is ready to be operated safely at all times under various operating conditions and fields. One form of implementation of the task of fostering material Worthiness within the Navy is through material Worthiness surveys by Dislaikmatal officers. The implementation of the Dislaikmatal role is very important to minimize the loss of defense equipment and non-defense equipment. One of the losses suffered by the Navy recently was the example of the burning and sinking of the KRI Rencong-622 in the waters of Sorong, West Papua, about 20 nautical miles from the dock of the Indonesian Navy Fleet Command III in Sorong (Media, 2018). Although Dislaikmatal did not directly oversee the process of escorting and operating the ship, Dislaikmatal perceived to be partly responsible for the incident. Therefore Dislaikmatal needs to always maintain and improve the professionalism of its officers. The use of the latest technology in the Indonesian Navy Alutsista requires equipment and relevant methods so that proper material Worthiness tests can be carried out. Facing technological developments and the need for adjustments to existing survey methods, officers of the Material Worthiness Agency of the Indonesian Navy (Dislaikmatal) need to constantly update their knowledge and skills in the field of material Worthiness surveys through various education and training programs in order to maintain and improve their professionalism and performance, as well as performance organization comprehensively. On the other hand, the development of Dislaikmatal officers requires long time and process to produce officers who are able to adapt to the demands of the work at hand. In addition, Dislaikmatal officers are Navy soldiers who have to carry out rotations and transfer assignments in other services to support the development of their career coaching. Therefore, it is perceived the need for transformational leadership of Dislaikmatal that is able to encourage every employee of Dislaikmatal to develop self-ability and work commitment to face work challenges and personal professional development needs.

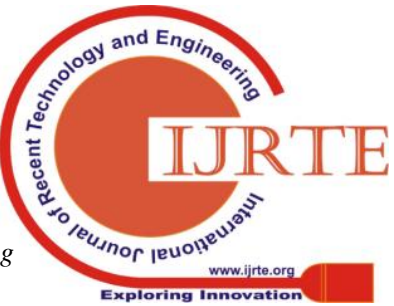




\section{Facing Industrial Era 4.0 Through Officers' Professionalism Improvement: Analysis of Indonesian Navy Material Worthiness Service Department.}

Eventhough the important role of leaders of the Material Worthiness Agency of the Indonesian Navy (Dislaikmatal) that is transformational has been conveyed in the above discussion, however the effect of transformational leadership with self-efficacy characteristic, competence and commitment to professionalism of Dislaikmatal officers have never been implemented yet. Recognizing the important role of management of officer professionalism for the achievement of Dislaikmatal success, this research was carried out contextually to determine the effect of transformational leadership, self-efficacy, competence and work commitment on the professionalism of Dislaikmatal officers.

This study will provide an indicator formulation of transformational leadership of Dislaikmatal, competencies and work commitments that are in accordance with the context of Dislaikmatal's performance and formulate elements of officer professionalism of Dislaikmatal needed to improve the performance of the Material Worthiness Agency of the Indonesian Navy (Dislaikmatal). Reviewing from the leadership literature, the importance of transformational leaders was expressed by Bass according to the following quote, Transformational leaders have the ability to change organizations through employee vision for the future, and by clarifying officers vision, officers can empower officers to take responsibility for achieving that vision.

These leaders usually display four different behaviours: ideal influence, inspirational motivation, intellectual stimulation, and individual consideration (Buil, Martínez, \& Matute, 2018). In the description, Bass states that transformational leaders have the ability to change organizations through employee vision for the future, and by clarifying employee vision, officers can empower officers to take responsibility for achieving that vision.

\section{LITERATURE REVIEW}

\section{A. Professionalism}

Professionalism is the attitude of the members of the profession who truly master and take seriously their profession. In the management literature the employee professionalism is defined as follows, “...the individual professional is one who works within limitations set by the boundaries of knowledge specialism set by the professional body, and government control in terms of designated targets and plans that others have set for them (Parnell, 2011) John A Parnell's study on professionalism describes that a person is declared a professional if the person is able to demonstrate his performance within the boundaries arranged in a series of specific knowledge determined by a professional body and in the target and planning context set by government.

Furthermore John A. Parnell explains the definition of professionalism as follows: Whereby professionalism was defined via lists of traits, typically: theoretical knowledge obtained in a professional training school; application of this knowledge in practice; working for the greater good; altruism; remuneration on a fee-for-service basis and self-regulation and autonomy (Parnell, 2015). A professional must master the knowledge gained through professional training, apply that knowledge in the world of work, carry out creativity and innovation in the fields he engages in and must always think positively by upholding ethics and professional integrity.

The same thing about professionalism was expressed by Brian P. West as follows: Professionalism is therefore characterized by the self directed application of knowledge to some function that serves a particular human need and an ongoing search for means by which that need might be better satisfied (West, 2003) Brian P West explains the characteristics of professionalism as a personal awareness to perform a function that serves the needs of others and is always looking for ways to be able to provide more satisfaction than what already exists. Based on this understanding, a professional can be identified through his characteristics as someone who masters a skill based on his formal knowledge and has the skills to apply that knowledge in the daily workforce and always devotes his time to improving his service as a result of job satisfaction and customer satisfaction.

Another definition of professionalism can be taken from The Merriam-Webster dictionary which defines it as follows: Professionalism as the conduct, aims, or qualities that characterize or mark as a proffesion or professional person and it define a profession as a calling requiring specialized knowledge and often long and intensive academic preparation (Daniel Porcupile, n.d.). In the dictionary professionalism is defined as behavior, purpose, or quality that is characteristic or a sign of a profession or professional person, and to carry the professional nickname requires special knowledge and generally requires long and intensive academic preparation.

Furthermore, the characteristics of professionalism are also characterized by the ability to understand changes that occur in a short time according to Peter Fusaro's description as follows, "although these measurements offer risk managers and traders an excellent snapshot of risk at a given moment in time, a true professional is also aware of how these indicators will change with market movement and time (Fusaro, 2008). Furthermore, about professionalism, it is indicated that professionalism is not related only to the work done but is more broadly related to aspects of attitude, behavior, expertise, quality, expertise held and expertise in working. Chambers describes the details of professionalism cited by Brian P. West as follows: Professionalism is tolerated: to contend that managers shall have what they demand, where what they demand may prejudice the preservation of the interests of others or the exercise of judgment by others, is to forgo professional independence; to admit that intellectual or emotional involvement or self-interest dominate (West, 2003) Professionalism is competition between officers in meeting the criteria or requirements possessed by officers in work that have been determined by the organization. In addition, professionalism can foster intellectual freedom of the officers at work and foster an atmosphere that is conducive to work. Other researcher about professionalism, Catherine D. 
Deangelis, defines professionalism as '... the ability to show caring and competence in a manner to be Worthiness of and engender the continued trust and confidence of the public in our profession (DeAngelis, 2014). A professional must be able to prove his competence in working in accordance with the standards set for colleagues or leaders, which in turn will foster a sense of trust from colleagues and other parties related to the ability of the person in mastering and completing every job submitted to him.

\section{B. Transformational Leadership}

Pieterse explains transformational leadership as follows: Transformational leadership defined as a style of leadership that transforms followers to rise above their self-interest by altering their morale, ideals, interests, and values, motivating them to perform better than initially expected, is currently the most widely accepted paradigm in the leadership literature (Buil et al., 2018). Transformational leadership is the style of a leader who changes the mindset of his followers not to think about their personal interests by changing morals, ideals, desires and values; motivate followers to provide performance that exceeds the expected limits. The concept of transformational leadership is the most widely accepted concept in the current leadership literature.

Elain Pieterse, Cornelia Niessen define transformational leadership as follows: "transformational leadership is defined as a meaningful and creative exchange between leaders and followers with the aim to guide followers through a vision-driven change (Niessen, Mäder, Stride, \& Jimmieson, 2017) In accordance with Cornelia's understanding, transformational leadership is a style of a leader who builds beneficial and creative reciprocal relationships to move his followers through a change in perspective on organizational goals.

Aviolo and Bass define transformational leadership as follows: Transformational leadership is multi-faceted and comprises four sub-dimensions, namely idealized influence (attributed and behavior), inspirational motivation, intellectual stimulation, and individualized consideration. Idealized influence attributed refers to followers' attributions of power and confidence and their identification with their leader. Leaders consider the need of others over their own needs and serve as charismatic role models for their followers, who respond with trust, confidence, and respect (Niessen et al., 2017).

Ricky W. Griffin and Greogry Moorhead define transformational leadership as a series of abilities of a leader according to the following quote: "transformational leadership is the set of abilities that allows the leader to recognize the need for change to create a vision to guide that change and to execute the change effectively (Griffin \& Moorhead, 2014) Transformational leadership is a set of capabilities of a leader that allows him to identify the need for organizational change through changes in the organization's vision and is able to apply the changes needed effectively.

This is in line with the research of John R. Schermerhorn, Jr., who stated that "transformational leadership occurs when leader broadens and elevates followers' interests and stir followers to look beyond their own interest to the good of other (Griffin \& Moorhead, 2014) Transformational leadership arises when a leader is able to expand and uplift the desires of his subordinates to see far higher than his personal interests for the good and the common good.

Besides that, Stephen P. Robbins and Timothy A. Judge said, "transformational leadership inspire followers to transcend their own self interests for the good of the organization and are capable of having a pro found and extraordinary effect on their followers (Robbins \& Judge, 2019) Transformational leadership can inspire subordinates to not prioritize self-interest but prioritize organizational interests for the good of the organization.

\section{Competence}

Etymologically the term "competence" comes from the English word "competency" which means skill or ability. Eraut and du Boulay define competence as follows: "Competence is broadly concerned with what a person is able to do ... the ability to perform tasks and roles to the expected standard". Eraut and du Boulay also commented on the competency definition of the ISO standard by stating "the International Standards Organisation defines it as ability to apply knowledge and skills to achieve intended results (Lester, 2014). Based on the excerpt above, competency can be understood as a fundamental characteristic of an individual, which is related to the reference criteria for effective performance. Competence is part of a person's personality that has been embedded and lasts a long time and can control behavior in various tasks.

This is in line with Spences \& Spencer's statement about competence: "competency is an underlying characteristic of an individual that is causally related to criterion-referenced effective and/or superior performance in a job or situation (Vathnophas \& Thai-ngam, 2007). Reference criteria means that competence actually predicts who is doing something good or bad, as measured by specific or standard criteria. Competence is thus a number of characteristics that underlie a person and show ways of acting, thinking, or generalizing the situation appropriately in the long run.

John R. Schermerhorn and Daniel G. Bachrach define competence as follows, 'competence represents your personal talents or job related capabilities. although extremely important, by itself competency won't guarantee success. You have to be committed (Schermerhorn, Jr \& Bahrach, 2015) Schermerhorn and Bachrach state that competence is a personal talent or work ability that is owned as seriously and is very important, even though competence is not $100 \%$ guaranteeing one's success if it is not accompanied by commitment to his work.

Furthermore Robbins and Coulter define competence as follows, "competence is technical and interpersonal knowledge and skills (Robbins \& Coulter, 2016) Robbins and Coulter's statement shows that competence is someone's technical knowledge that can be analyzed through his skills at work. In addition, competence is a reflection of one's knowledge in carrying out his work by combining knowledge and skills that will provide better results in the completion of his work. 


\section{Facing Industrial Era 4.0 Through Officers' Professionalism Improvement: Analysis of Indonesian Navy Material Worthiness Service Department.}

In line with the statement above, Jason A. Colquitt et.al stated the following on competence: Competence captures a person's belief in his or her capability to perform work taks successfully. Comptence is identical to the Self-efficacy concept reviewed previously in this chapter officers with a strong sence of competence (or self-efficacy) believe they can execute the particular behaviors needed to achieve success at work (Colquitt et al., 2015). Debra L. Nelson and James Campbell Quick define competence as follows, competence is the belief that one has the ability to do the job well. Without competence, officers will feel inadequate and lack a sense of empowerment (Nelson \& Campbell Quick, 2011). In line with the previous statement that competence is synonymous with self-efficacy, the Nelson and Quick statement also indicates that competence also contains a person's confidence in his ability to do a good job.

\section{Work Commitment}

Mowday et.al in his research on psychology of officers explains that "work commitment is a reflection of a more stable and general employee attitude, job satisfaction is a reflection of a more fragile and changeable employee attitude (Trice, Mowday, Porter, \& Steers, 1984). Work commitment as a reflection of the behavior of subordinates who are more stable and general in nature, while job satisfaction is a reflection of the behavior of subordinates who are more fragile and changeable. Another explanation of commitment is described by Morrow according to the quote as follows; Work commitment is a functional of personal characteristics, including dispositional qualities and presents a facet design of work commitment that includes work ethics, career commitment, organizational commitment either affective or continuance commitment, and job involvement (Sampath Kappagoda, Zainul, Othman, \& De Alwis, 2014). According to the quote above Morrow explains that work commitment is a person's functional characteristics which is also the quality of his personality. Work commitment is a combination of work ethics, commitment to a career, commitment to an organization is only a form of sympathy and formality, and involvement in work.

Rodney A. McCloy and Lauress L. Wise describe the importance of work commitment to the performance of a person and organization according to the following quote, "work commitment is very plausibly related to motivation to improve job performance and hence motivation to learn. If you are committed to your work, you are more likely to want to improve (Mccloy \& Wise, 2002) The explanation shows that work commitment is very closely related to motivation to improve performance, thereby increasing motivation to learn. If someone is committed to his work, the individual will always want to improve his abilities.

This is as stated by Lincoln and Kalleberg as follows Work commitment refers to the centrality of work to a person's overall identity and its importance in an individual's life. It is a global work value since it compares one's involvement in the work role to the other social roles the person plays (Lincoln \& Kalleberg, 1992). Lincoln and Kalleberg explain that work commitment refers to the core of a job towards one's general identity and the importance of the work in the life of the individual. Commitment is a global value of work

because commitment can be used to distinguish a person's involvement in his role according to his work towards other social roles. Similar explanations were made by Dean McFarlin and Paul Sweeney who explained that "work commitment ... refers to the importance of work in one's life the extent to which it is important value or motivator relatives to other general life (McFarlin \& Sweeney, 2011). Work commitment refers to the importance of a job to one's life, namely the extent to which work becomes an important value or motivator relative to other common things such as money, family, fun time.

Arne L. Kalleberg and Ivar Berg also see work commitment that refers to the importance of working in one's life, as quoted below: Work commitment refers to the importance of work in people's lives and is often conceptualized as workers central life interests. Workers who are highly commited to work are likely to express this through strong attachments to particular work structures, such as their class, occupation, work organization, and/or union and through criticisms of welfare recipients (Kalleberg \& Bergh, 2008)

\section{E. Theoretical Framework}

Transformational Leadership and Professionalism

Gary Yukl explained that a transformational leader can make the officers to be more confident and motivate the officers to be more professional: With transformational leadership, the followers feel trust, admiration, loyalty, and respect toward the leader, and they are motivated to do more than they originally expected to do. According to Bass, the leader transforms and motivates followers by making them more aware of the importance of task outcomes, inducing them to transcend their own self-interest for the sake of the organization or team, and activating their higher-order needs (Yukl, 2010) With transformational leadership followers or officers feel trust, admiration, loyalty and respect for leaders and officers are motivated to deliver performance that is more than the original target expected of employee performance. In accordance with the discussion in the previous sub-chapter of the discussion, according to Bass the transformational leader will be able to change and motivate the officers below to realize the importance of producing maximum performance, encouraging officers to think beyond personal interests in the interests of the organization and forming employee professional attitudes.

Based on the discussion in the description above, it is alleged that there is a positive direct effect of transformational leadership on professionalism.

\section{F. Competence And Professionalism}

Mabey emphasizes that employee management is basically making a policy about employment that is coherent and consistent to generate employee commitment to his work and organization. Here is the explanation: Mabey et al.follow this up by asserting that the heralded outcomes of human resource management are almost without exception unrealistically high. 
To put the concept of human resource management into practice involves strategic integration, developing a coherent and consistent set of employment policies, and gaining commitment. This requires high levels of determination and competence at all levels of management and a strong and effective human resource function staffed by business-oriented people (Armstrong \& Armstrong, 2009). Within officers which become the particular concerns are the competencies of workers at each managerial level with the hope that they can be managed by business-oriented leaders and can create professionalism of officers in working with several approaches in accordance with the needs and challenges facing the organization. This is reinforced by dilday research that proves the role of employee competency is one of the determinants of employee professionalism in work (Dilday et al., 2018). Competence is a reflection of the ability of an employee to work, an ability that is possessed to assist in the completion of work that is his duty.(Admiraal \& Berry, 2016).

Based on the description above, it can be assumed that there is a direct positive effect of competence on professionalism.

\section{G. Work Commitment And Professionalism}

Paula C. Morrow and Joe F. Goetz explain the concept of work commitment has been a concern of researchers in recent years, this shows that work commitment is important in the management of officers in organization, below is the explanation: The concept of work commitment has attracted a great deal of attention from many scholars in recent years. It entails loyalty toward a number of different work-related entities, among them one's job, career or profession, organization, union, and even the work itself. Managers have expressed a great deal of interest in this concept because officers who demonstrate high levels of commitment are assumed to be more motivated, more satisfied with their jobs, and less likely to leave their firms. (Morrow \& Goetz, 1988) Work commitment has become one of the concerns of experts in recent years, work commitment is a reflection of employee loyalty to work and organization. By committing to work someone an employee will work optimally and show the best. The level of loyalty to the work can reflect the professionalism of an employee at work, which is professionalism itself is the sincerity of someone in completing work with all that they have in order to get maximum results. Leaders explain that work commitment arises from a high sense of motivation within oneself, job satisfaction while working and resulting in a low sense of getting out of work besides that work commitments that are in the employee's office can affect the professionalism of the officers at work.

Based on the description above, it can be assumed that there is a positive direct influence on work commitment to professionalism.

\section{METHODOLOGY/MATERIALS}

The population in this research were officers of the Material Worthiness Agency of the Indonesian Navy consisting of high ranked officers, middle ranked officers, first ranked officers, non-commissioned officers, enlisted ranked officers and civil servants. The sample in the research is a part of the population. The sampling technique used is Random Sampling, which is a simple random sampling method. Affordable target population of staff and soldiers in the Material Worthiness Agency of the Indonesian Navy, which amounted to 180 . The samples obtained were $=124$ officers.

Path Coefficient in the First Model Substructure

Table of Results of Significance Test and Regression Linearity Test

\begin{tabular}{|c|c|c|c|c|c|}
\hline \multirow{3}{*}{$\begin{array}{c}\text { Regressi } \\
\text { on }\end{array}$} & \multirow{3}{*}{$\begin{array}{c}\text { Equation of } \\
\text { Regression }\end{array}$} & \multicolumn{2}{|c|}{ Signifcance Test } & \multicolumn{2}{|c|}{ Linearity Test } \\
\hline & & \multirow{2}{*}{$F_{\text {calculation }}$} & $\mathbf{F}_{\text {table }}$ & \multirow{2}{*}{$\mathbf{F}_{\text {calculation }}$} & $\mathbf{F}_{\text {table }}$ \\
\hline & & & $\alpha=0.05$ & & $\alpha=0.05$ \\
\hline $\mathrm{Y}$ on $\mathrm{X}_{1}$ & $\begin{array}{l}\hat{Y}=67.60+ \\
0.39 X_{1}\end{array}$ & $\beta 1,830 * *$ & 3.92 & $0.703^{\mathrm{ns}}$ & 1.62 \\
\hline $\mathrm{Y}$ on $\mathrm{X}_{3}$ & $\begin{array}{l}\hat{Y}=101.70+ \\
0.77 X_{3}\end{array}$ & $30,882 * *$ & 3.92 & $0.844^{\mathrm{ns}}$ & 1.78 \\
\hline $\mathrm{Y}$ on $\mathrm{X}_{4}$ & $\begin{array}{l}\hat{Y}=55.07+ \\
0.52 X_{4}\end{array}$ & $46,472 *:$ & 3.92 & $1.333^{\mathrm{ns}}$ & 1.63 \\
\hline
\end{tabular}

Path Coefficient in the First Model Substructure

The structural equation formed in the first substructure model consists of 3 path coefficients from variables $\mathrm{X} 1$ to $\mathrm{Y}$, $\mathrm{X} 3$ to $\mathrm{Y}$, and $\mathrm{X} 4$ to $\mathrm{Y}$ in the form: $\mathrm{Y}=$ py1X1 + py3X3 + py $4 \mathrm{X} 4+$ pye 1 . With a magnitude (Ry.134) $2=0.6574$ so pye $1=0.585$. So the form of structural equations in the first sub-structure model: $\mathrm{Y}=0.314 \mathrm{X} 1+0.286 \mathrm{X} 3+0.292 \mathrm{X} 4+$ 0.585 . The description of path coefficient estimation is explained in table 4.31 and visualized through the following image display:

Tablel. Results of SPSS Model

\begin{tabular}{|c|c|c|c|c|c|}
\hline \multirow[b]{2}{*}{ Model } & \multicolumn{2}{|c|}{$\begin{array}{l}\text { Unstandardize } \\
\text { d Coefficients }\end{array}$} & \multirow{2}{*}{$\begin{array}{c}\begin{array}{c}\text { Standa } \\
\text { rdized } \\
\text { Coeffic } \\
\text { ients }\end{array} \\
\text { Beta }\end{array}$} & \multirow[b]{2}{*}{$\mathbf{t}$} & \multirow[b]{2}{*}{ Sig. } \\
\hline & B & $\begin{array}{l}\text { Std. } \\
\text { Error }\end{array}$ & & & \\
\hline \begin{tabular}{l|l}
1 & (Constant)
\end{tabular} & 41.128 & 9.416 & & 4.368 & .000 \\
\hline \begin{tabular}{|l} 
Transformat \\
ional \\
Leadership \\
(X1) \\
\end{tabular} & .241 & .065 & .281 & 3.726 & .000 \\
\hline $\begin{array}{l}\text { Competence } \\
(\mathrm{X} 3)\end{array}$ & .463 & .130 & .270 & 3.569 & .001 \\
\hline $\begin{array}{l}\text { Work } \\
\text { Commitmen } \\
\mathrm{t}(\mathrm{X} 4)\end{array}$ & .313 & .079 & .317 & 3.960 & .000 \\
\hline
\end{tabular}

The results of the estimation of the first structural model are then shown in the following figure : 
Facing Industrial Era 4.0 Through Officers' Professionalism Improvement: Analysis of Indonesian Navy Material Worthiness Service Department.

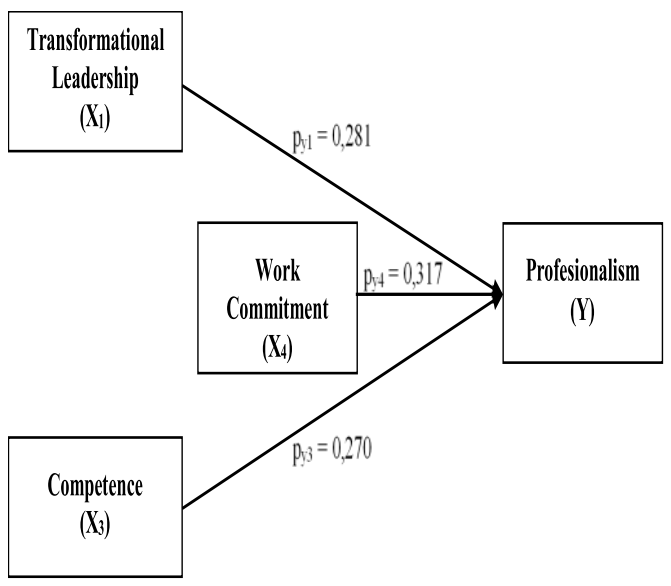

\section{RESULTS AND FINDINGS}

The results obtained after conducting a model analysis are used as a basis in answering hypotheses and drawing conclusions in this research. Explanation of the answers to these hypotheses can be described as follows:

Positive Direct Effect of Transformational Leadership (X1) on Professionalism (Y) The analysis results of the first hypothesis produce findings that transformational leadership has a direct positive effect on professionalism. Based on these findings it can be concluded that professionalism is directly influenced positively by transformational leadership. Increasing transformational leadership will lead to increased professionalism. The results of this study are in line with the opinions of some experts including Gary Yulk which explains that a transformational leader can make officers more confident and motivate their officers to be more professional. This is very much needed especially in Dislaikmatal in line with the very important role of Dislaikmatal in the environment of the Indonesian Navy organization which has responsibility for all material Worthiness both defense equipment and non-defense equipment. Officers expect leaders to be there when officers face problems such as providing space to communicate and expect assistance or solutions to what happens in the field. In this way, officers feel trust, admiration, and more respect for their leaders (Buil et al., 2018). According to Bass, transformational leaders can change and motivate their subordinates to perceive tasks that they receive not just administrative tasks but rather become part of their valuable lives. (Yukl, 2010). A transformational leader will continue to update all developments that occur in his field, through the latest technology tools the leader will help facilitate both the facilities and infrastructure needed in the field on duty, and this has been proven to increase the officers' professionalism (Patel, Lidor, Sanyal, Goepfert, \& Hueppchen, 2018). In addition to facilities and infrastructure, a transformational leader is expected to be able to create managerial in the organization in accordance with the needs and workload in the hope that the balance of the organization will be created and the ease in the process of control (Berghout et al., 2018).

\section{A. Direct Effect Of Positive Competitive (X3) On Professionalism (Y)}

The analysis results of the second hypothesis produce findings that competence has a direct positive effect on professionalism. Based on the findings, it can be concluded that professionalism is directly influenced positively by competence. Increased competence will lead to increased professionalism. The results of this research are in line with previous research conducted by Mabey, in the staffing management carried out is the employment arrangement in accordance with the competence in the field of work, this is expected to affect the level of professionalism of officers in working. (Armstrong \& Armstrong, 2009). In Dislaikmatal this has become a major concern by increasing officer competencies by providing training in accordance with their fields of work. This is reinforced by Dilday's research that proves the competencies that officers have can facilitate work and help improve the professionalism of officers in working (Dilday et al., 2018). The competence itself is a reflection of the ability of an employee to work, an ability that is possessed to assist in the completion of work that is his duty (Admiraal \& Berry, 2016). Officer competencies can be improved through an ongoing training process (Taormina et al., 2018). It is expected that Dislaikmatal leaders will pay more attention to officers who already have more competence and achievement and are expected to be able to be rewarded both financially and non-financially in the hope of increasing the professionalism of officers in their work.

\section{B. Direct Effect of Positive Work Commitment (X4) on Professionalism (Y)}

The analysis results of the third hypothesis produce findings that work commitment has a positive direct effect on professionalism. Based on these findings it can be concluded that professionalism is directly influenced positively by work commitment. Increasing work commitment will lead to increased professionalism. The results of this study are in line with the opinions of several experts including Paula C. Morrow and Joe F. Goetz which explains the concept of work commitment has been a concern of researchers in recent years, this shows that work commitment is important in managing officers in the following organizations the explanation. The higher officer work commitment is assumed that officers will be more motivated at work and more loyal to their jobs indirectly will be more professional in their work (Morrow \& Goetz, 1988) In addition, the ethics and spirit of being responsible for work that has been carried out have a role in forming job professionalism (Abou Arraj, 2018). This should continue to be fostered and developed in Dislaikmatal for all officers. Professionalism itself is the basic element of bureaucracy in an organization (Abou Arraj, 2018). Every generation has a different pattern, this should be the attention of leaders because it is proven that Generation have a role in the formation of one's professionalism at work (Stone-Johnson, 2017) besides that work ethic has proven to be one of the factors that can affect professionalism (Harris, 2017) It is expected that leaders can maintain the work ethic of officers in working with various approaches. 


\section{CONCLUSIONS}

1. Transformational leadership has a positive direct effect on professionalism. It means that the Material Worthiness Agency requires leaders who have a far-sighted future by mobilizing officers' awareness of the importance of the work they do to complete in a timely and quality manner.

2. Competence has a positive direct effect on professionalism. This means that the ability to work that officers have in work can support the professionalism level of officers.

3. Work commitment has a positive direct effect on professionalism. It means that based on the results of this study, it shows the main role in forming the professionalism level of officers. The recommendations are:

a) The leaders of Dislaikmatal should provide opportunities for officers to develop their abilities through the field of education such as providing training, seminars, conferences in accordance with the field of Worthiness.

b) The leaders should build access to communication (cooperation or MOU) with relevant parties to Disalaikmatal.

c) The leaders should build system that enables the creation of communication and information in real time for every activity of Dislaikmatal officers.

d) The leaders of Dislaikmatal must pay attention to the level of welfare of officers covering career paths, Education, Housing, Transportation and Health.

\section{REFERENCES}

1. Abou Arraj, H. (2018). Professionalism among officers in Lebanon: the Lebanese University. World Journal of Entrepreneurship Management and Sustainable Development, WJEMSD-04-2018-0042. https://doi.org/10.1108/WJEMSD-04-2018-0042

2. Admiraal, W., \& Berry, A. (2016). Video narratives to assess student teachers' competence as new teachers. Teachers and Teaching, 22(1), 21-34. https://doi.org/10.1080/13540602.2015.1023026

3. Armstrong, M., \& Armstrong, M. (2009). Armstrong's handbook of human resource management practice (Eleventh ed). London; Philadelphia: Kogan Page.

4. Berghout, M. A., Oldenhof, L., Fabbricotti, I. N., \& Hilders, C. G. J. M. (2018). Discursively framing physicians as leaders: Institutional work to reconfigure medical professionalism. Social Science and Medicine, 212(July), $68-75$. https://doi.org/10.1016/j.socscimed.2018.07.013

5. Buil, I., Martínez, E., \& Matute, J. (2018). Transformational leadership and employee performance: The role of identification, engagement and proactive personality. International Journal of Hospitality Management, (October 2017) https://doi.org/10.1016/j.ijhm.2018.06.014

6. Colquitt, J., LePine, J. A., \& Wesson, M. J. (2015). Organizational behavior: improving performance and commitment in the workplace (Fourth edition). New York, NY: McGraw-Hill Education.

7. Daniel Porcupile. (n.d.). What is PROFESSIONALISM. Retrieved November 19, 2018, from https://www.linkedin.com/pulse/what-professionalism-does-mean-yo u-daniel-w-porcupile/

8. DeAngelis, C. D. (2014). Patient Care and Professionalism. New York: Oxford University Press.

9. Dilday, J. C., Miller, E. A., Schmitt, K., Davis, B., \& Davis, K. G. (2018). Professionalism: A Core Competency, but What Does it Mean? A Survey of Surgery Residents. Journal of Surgical Education, 75(3), 601-605. https://doi.org/10.1016/j.jsurg.2017.09.033

10. Fusaro, P. (2008). The ProfessionalRisk Manager Guide To The Energy Market. New York: Mc Graw-Hill.

11. Griffin, R. W., \& Moorhead, G. (2014). Organizational behavior: managing people and organizations (11th Edition). Australia: South-Western/Cengage Learning.

12. Harris, J. (2017). "Altruism: Should it be included as an attribute of medical professionalism?" Health Professions Education, 1-6. https://doi.org/10.1016/j.hpe.2017.02.005

13. Kalleberg, A. K., \& Bergh, I. (2008). Work and Industry Structure Markets and Processess. New York: Psychology Press.

14. Lester, S. (2014). Professional standards, competence and capability. Higher Education, Skills and Work-Based Learning, 4(1), 31-43. https://doi.org/10.1108/HESWBL-04-2013-0005

15. Lincoln, J. R., \& Kalleberg, A. L. (1992). Culture, Control and Commitment A Study of Work Organization and Work Attitudes in United State. New York: University Press.

16. Mccloy, R. A., \& Wise, L. L. (2002). Invited reaction: The effects of personality , affectivity , and work commitme ..., 13(4), 377-382.

17. McFarlin, D., \& Sweeney, P. (2011). International Management Strategic Opportunitues and Cultural Challenges. New York: Routledge.

18. Media, K. C. (2018, September 11). Kronologi Terbakar dan Tenggelamnya KRI Rencong-622. Retrieved November 19, 2018 , from

https://regional.kompas.com/read/2018/09/11/23151931/kronologi-t erbakar-dan-tenggelamnya-kri-rencong-622

19. Morrow, P. C., \& Goetz, J. F. (1988). Professionalism as a form of work commitment. Journal of Vocational Behavior, 32(1), 92-111. https://doi.org/10.1016/0001-8791(88)90008-5

20. Nelson, D. L., \& Campbell Quick, J. (2011). Organizational Behavior Science,the Real World and You (7th ed.). United State: South-Western Cengage Learning.

21. Niessen, C., Mäder, I., Stride, C., \& Jimmieson, N. L. (2017). Thriving when exhausted: The role of perceived transformational leadership. Journal of Vocational Behavior, 103, 41-51. https://doi.org/10.1016/j.jvb.2017.07.012

22. Parnell, J. A. (2011). Article information: Journal of Advances in Management Research, 11, 232-256. http://dx.doi.org/10.1108/MRR-09-2015-0216

23. Parnell, J. A. (2015). Patient-Centerd Professionalism in Pharmacy: Values and Behaviours. Journal of Health Organization and Management, 29(3), 413-430. http://dx.doi.org/10.1108/MRR-09-2015-0216

24. Patel, S., Lidor, A., Sanyal, A., Goepfert, A. R., \& Hueppchen, N. (2018). Smartphone Use and the Perception of Professionalism Among Medical Students and Surgical Faculty. Journal of Surgica Education, $\quad 75(2)$ https://doi.org/10.1016/j.jsurg.2017.07.027

25. Robbins, S. P., \& Coulter, M. K. (2016). Management (13th edition). Boston: Pearson.

26. Robbins, S. P., \& Judge, T. A. (2019). Organizational Behavior (18th ed.). England: Pearson Education Limited.

27. Sampath Kappagoda, U. W. M. R., Zainul, H., Othman, F., \& De Alwis, G. (2014). Psychological Capital and Job Performance: The Mediating Role of Work Attitudes. Journal of Human Resource and $\begin{array}{lll}\text { Sustainability } & \text { Studies, } & \text { 2(2), }\end{array}$ https://doi.org/10.4236/jhrss.2014.22009

28. Schermerhorn, Jr, J. R., \& Bahrach, D. G. (2015). Introduction to Management (13th ed.). Asia: Wiley.

29. Stone-Johnson, C. (2017). Autonomy, professionalism, and the role of generation in professional capital. Journal of Professional Capital and Community, 2(1), https://doi.org/10.1108/JPCC-10-2016-0024

30. Taormina, D. P., Zuckerman, J. D., Karia, R., Zabar, S., Egol, K. A., \& Phillips, D. P. (2018). Clinical Skills and Professionalism: Assessing Orthopaedic Residents With Unannounced Standardized Patients. Journal of Surgical Education, 75(2), 427-433 https://doi.org/10.1016/j.jsurg.2017.08.001

31. Trice, H. M., Mowday, R. T., Porter, L. W., \& Steers, R. M. (1984). Employee Organization Linkages: The Psychology of Commitment, Absenteeism, and Turnover. Contemporary Sociology, 13(1), 90. https://doi.org/10.2307/2068333

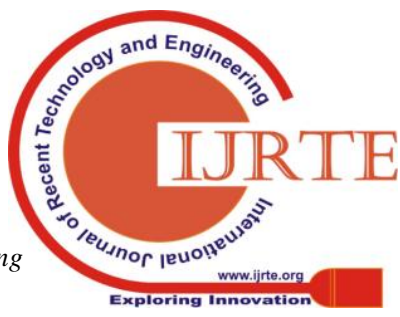


Facing Industrial Era 4.0 Through Officers' Professionalism Improvement: Analysis of Indonesian Navy Material Worthiness Service Department.

32. Vathnophas, V., \& Thai-ngam, J. (2007). Competency Requirements for Effective Job Performance in The Thai Public Sector. Contemporary Management Research, 3(1), 45-70. http://dx.doi.org/10.7903/cmr.49

33. West, B. P. (2003). Professionalism and Accounting Rules. Routledge. https://doi.org/10.4324/9780203380628

34. Wirawan. (2015). Manajemen Sumber Daya Manusia Indonesia, Teori,, Psikologi, Hukum, Ketenagakerjaa, Aplikasi dan Penelitian. Jakarta: PT. Raja Grafindo Persada.

35. Yukl, G. A. (2010). Leadership in organizations (7th ed). Upper Saddle River, N.J: Prentice Hall.

\section{AUTHORS PROFILE}

I am Mulyadi, Affiliated with Human Resources Management, Universitas Negeri Jakarta, Jakarta Timur, 13220, Indonesia., mulyadi.unj30@gmail.com

My name is R.Madhakomala, working with Faculty of Education, Universitas Negeri Jakarta, Jakarta Timur, 13220, Indonesia.

I am Kazan Gunawan, currently affiliated with Human Resources Management, Universitas Negeri Jakarta, Jakarta Timur, 13220, Indonesia 